\title{
Studies on preparation of leaf protein concentrate from leaves of Amaranthus hybridus, Moringa oleifera and Leucaena leucocephala and its utilization in weaning food
}

\author{
- R.N. MedA*, A.R. SAwate, B.M. PATIL and R.B. KShiRSAGaR \\ Department of Food Engineering, College of Food Technology, Vasantrao Naik Marathwada Krishi Vidyapeeth, PARBHANI \\ (M.S.) INDIA \\ Email: medarohit4@gmail.com

SUMMARY :

Protein deficiency and protein calorie malnutrition (PCM) is one of the major nutritional problems in the developing world. As a novel source to combat malnutrition, leaf protein concentrate was prepared and further utilized in weaning food. Three different leaves: Amaranthus hybridus, Moringa oleifera and Leucaena leucocephala (Subabul) were utilized for leaf protein concentrate (LPC) preparation. AMS (Amaranth, Moringa and Subabul) mix consisting of LPC from each leaf at the ratio of 1:1:1 was further studied. Proximate analysis of AMS mix showed protein content as 36.48 per cent and moisture content as 8 per cent. Weaning food was prepared using wheat, mung bean and rice to which LPC mix was incorporated. On the basis of sensory evaluation, sample with 2 per cent LPC mix was selected. Nutritional analysis of the weaning food showed protein content as 19.26 per cent and ash content as 2.6 per cent. Thus, formulation of weaning food with LPC makes the food more nutritious thereby alleviating the problem of malnutrition.

KEY WORDS : Malnutrition, Leaf protein concentrate (LPC), Weaning food, Protein, AMS mix

How to cite this paper : Meda, R.N., Sawate, A.R., Patil, B.M. and Kshirsagar, R.B. (2017). Studies on preparation of leaf protein concentrate from leaves of Amaranthus hybridus, Moringa oleifera and Leucaena leucocephala and its utilization in weaning food. Internat. J. Proc. \& Post Harvest Technol., 8 (2) : 89-94. DOI: 10.15740/HAS/IJPPHT/8.2/89-94. 